\title{
BEVÁNDORLÁS VAGY AUTOCHTÓNIA, INTEGRÁCIÓ VAGY APARTHEID? VITÁK A KORA KÖZÉPKORI ANGLIA TÖRTÉNETI GENETIKAI ÖSSZETÉTELÉNEK ÉRTELMEZÉSÉRŐL
}

\section{IMMIGRANTS OR LOCALS, INTEGRATION OR APARTHEID? DEBATES ON THE INTERPRETATION OF THE GENETIC COMPOSITION OF EARLY MEDIEVAL BRITAIN}

\author{
Koncz István \\ tudományos segédmunkatárs, ELTE Régészettudományi Intézet \\ fredgar22@gmail.com
}

ÖSSZEFOGLALÁS

\begin{abstract}
A kora középkori régészet mindig kitüntető figyelemmel kezelte a különböző népek és csoportok vándorlását, de ezek értelmezése és magyarázata folyamatosan változott. Az utóbbi évtizedekben a nagy tömegeket megmozgató migrációkról inkább a helyi fejlődésre és kulturális átalakulásra, esetleg a kis létszámú, katonai csoportok vándorlására helyeződött a hangsúly. Az új természettudományos módszerek (elsősorban izotópos és genetikai vizsgálatok) és az általuk szolgáltatott, a régészet által eddig hozzáférhetetlen adatok segítségével lehetőség nyílt a kérdéskör felülvizsgálatára. Több kutatási projekt vizsgálta az angolszász vándorlást (Kr. u. 5-8. század) mind történeti, mind modern mintákon végzett genetikai vizsgálatokkal. Ezek intenzív párbeszéd kialakulásához vezettek a régészek és a genetikusok között, nemcsak az említett vándorlás jellegét és kiterjedését (a vizsgálatok bebizonyították, hogy a vándorlások megtörténtek, és ezzel visszahozták a köztudatba a tömeges migrációk elméletét), hanem a genetikai (és más természettudományos) vizsgálatok történeti/régészeti alkalmazhatóságát illetően is. Bár a pontos hatása ennek az új „tudományos forradalomnak” még egyértelműen nem mérhető fel, a két tudományág együttműködése vitathatatlanul új eredményekhez és új kérdésekhez, valamint a régi problémák újraértelmezéséhez vezet.
\end{abstract}

\section{ABSTRACT}

Migrations have always been in the focus of early medieval archaeology, even if there were periodic shifts of emphasis in their interpretation. During the past decades, theories of large-scale migrations have been supplanted by narratives of local development, innovation and different types of cultural transformations. New scientific methods (mainly isotope and DNA analyses) have enabled a re-assessment of these issues. Several research projects devoted to the AngloSaxon migration $\left(5^{\text {th }}-8^{\text {th }}\right.$ centuries $\left.A D\right)$ involved the sampling of both modern and ancient DNA, which led to an intense dialogue and discussion between archaeologists and geneticists not 
only about the scale or nature of the aforementioned migration - given that DNA analyses proved that migration had indeed taken place - but also on the applicability and potentials of genetics (and all scientific methods) in archaeology. While the broader impact of this new scientific revolution yet remains to be seen, it is obvious that the collaboration between the two disciplines can yield significant new results (while raising also a spate of new questions) and lead to the re-interpretation of old problems.

Kulcsszavak: DNS, történeti genetika, angolszász Anglia, vándorlás

Keywords: DNA, archaeogenetics, Anglo-Saxon England, migration

A különböző népek vándorlásai és azok hatása mindig is központi szerepet töltöttek be a népvándorlás és a kora középkor kutatásában. Elsősorban a régészeti leletanyag etnikus meghatározásának korlátai és lehetőségei körül kialakult vita következtében az elmúlt évtizedekben megjelent a régészetben egy olyan kutatási irányzat, mely a - széles körü, nagy tömegeket megmozgató - migrációval szemben inkább a helyi fejlődésre, innovációra, kulturális átalakulásra és azok formáira helyezte a hangsúlyt. (Összefoglalóan lásd Hakenbeck, 2008.) A különböző természettudományos vizsgálatok bevonásával a régészet a problémák új nézőpontú megközelítését és új kérdések feltételét célozza. A genetikai vizsgálatok, melyek eredményei a régészetben csupán napjainkban kezdik igazán éreztetni hatásukat, egy, a tárgyi kultúrától független információforrást kínálnak a történeti migrációk kérdéskörének jobb megértéséhez. Nem meglepő tehát, hogy az első igazi tudományos diskurzus genetikusok és régészek között ebben a témában, a kora középkor tekintetében pedig az angolszász vándorlás kapcsán alakult ki, ez utóbbi azonban túlmutatott magát a vándorlást közvetlenül érintő problémakörön, $\mathrm{s}$ alapvető kérdéseket vetett fel a genetikai eredmények régészeti hasznosításával kapcsolatban.

Az angolszász vándorlást érintő első genetikai vizsgálatok modern mintákon alapultak, azok minden előnyével (könnyen hozzáférhető, kiváló állapotú, viszonylag olcsó) és hátrányával. Ezek azt feltételezték, hogy a mintát adó egyének a vizsgálni kívánt történeti populáció leszármazottai, illetve hogy a modern és történeti népesség sokszínüsége változatlan. Két, egymástól független kutatási program tűzte ki célul, hogy meghatározza, milyen mértékủ kontinentális betelepülésnek volt kitéve a brit sziget a történelem folyamán (Weale et al., 2002; Capelli et al., 2003.). Mindkettő az Y-kromoszóma vizsgálatán alapult, ami a férfiági leszármazás vizsgálatára alkalmas.

A két vizsgálat során alkalmazott mintavétel szempontrendszere nagyon hasonló: a minták ötezer fó alatti kisvárosokból származnak, olyan férfiaktól, akik helyi születésüek, illetve apai nagyapjuk is bizonyíthatóan helyi lakos volt. Az előírások a nagyfokú, modern migráció, illetve személyi mobilitás zavaró hatásá- 
nak kiszürését, vagy legalábbis csökkentését célozták. ${ }^{1}$ A vizsgálatok a helyiként meghatározott és a kontinentális genetikai állományok összevetésén alapultak. Michael E. Weale és kutatócsoportja öt közép-angliai és két walesi városból egyfajta keresztmetszetként, összesen 313 személytől vett mintával (helyiek) dolgozott, melyeket fríz, illetve norvég mintasorokkal (kontinentálisak) vetettek össze. A Cristian Capelli által vezetett vizsgálat jóval nagyobb mintaszámmal, huszonöt helyszínről begyüjtött 1772 mintával a lehető legreprezentatívabb mintavételre törekedett ${ }^{2}$, az összehasonlításhoz norvég, dán, illetve észak-németországi mintasorokat használt.

A vizsgált mintasorok genetikai távolsága egy fökomponens-analízis segítségével került megjelenítésre, s a két vizsgálat eredményei összecsengtek. A Wealeék által vizsgált öt közép-angliai város a genetikai minták távolsága alapján egy tömböt alkotott, melybe jól illeszkedett a frízföldi, ám jelentősen eltértek a walesi és norvég mintasorok. A jóval több mintavételi helyszínnel dolgozó Capelli-projekt esetében a nagyon elkülönülő norvég, északnémet és dán, valamint az Orkney-, illetve Shetland-szigetekröl származó mintasorokkal szemben - éppen nagyfokú eltérésük miatt - egy klasztert alkottak a mai Anglia, Skócia és Írország területéről származó minták. A klaszter, minden összetartása ellenére korántsem egységes, inkább egy norvég-ír-északnémet/dán háromdimenziós rendszerként képzelhető el, ahol például York és Norfolk ez utóbbihoz közel, Orkney és Shetland az előbbi felé félúton helyezkednek el, míg az ír és a walesi minták saját kis csoportot alkotnak. Mindkét vizsgálat a kontinentális genetikai állomány nagyon magas arányát határozta meg: Weale-ék ezt régiónként eltérő módon 50-100\%ban, míg Capelliék 24,4-72,5\%-ban adták meg. Tehát az adott pillanatban a terület férfilakossága ilyen arányban rendelkezett volna kontinentális felmenőkkel, ám hogy ez a keveredés milyen módon, vagy pontosan mikor ment végbe, arra nézve a vizsgálatok pontos információval nem szolgáltak.

A genetikai eredmények régészeti-történeti interpretációja két irányból indult meg: egyrészt a regionális különbségek, másrészt pedig a kontinentális génállomány, s ezzel együtt a bevándorló férfiak meglepően magas arányának magyarázatával. A két kérdéskör egymástól szétválaszthatatlan. Amennyiben elfogadjuk azokat a számításokat, melyek szerint a mai Anglia területén a római kort követően a lakosság száma kétmillió körül lehetett (Millett, 1990 alapján), amelynek felét jelentették a férfiak, úgy a betelepülö férfiak száma a genetikai vizsgálatokból következő arányok szerint több százezerre tehető. Bár ez az adat részben

${ }^{1}$ A szociológiai megfigyeléseken túl, már történeti DNS-en alapuló esettanulmányok is bizonyítják, hogy az alacsony lakosságú települések kevésbé vannak kitéve a modern kori migrációnak (Vai et al., 2015).

${ }^{2}$ Anglia területét egy 3x5-ös ráccsal felosztották, s a sarokpontokhoz legközelebb eső, történelmi kisvárosok lakosságából vettek mintát, kiegészítve olyan - a rácson érthető okokból kívül eső - helyszínekkel, mint az Orkney-, illetve a Csatorna-szigetek, valamint két írországi város. 
összecseng azzal a régészeti jelenséggel, hogy az angolszász vándorláshoz kötött, új anyagi kultúra megjelenésével a helyi alaplakosság szinte láthatatlanná válik (Härke, 2007), ez a szám akkor is jóval meghaladja a korszakban vándorló népek nagyságrendjét célzó becsléseket. E jelenség első magyarázata egy szegregált, lényegében apartheidszerü berendezkedéssel számolt az angolszász Angliában (Thomas et al., 2006), mely akkora gazdasági-társadalmi előnyben részesítette volna a politikai hatalmat gyakorló, új betelepülőket, amely már a reprodukció sikerére is kihatással lett volna. Ebben az esetben a betelepülö férfiak jóval kisebb száma mellett is kialakulhatott a kontinentális génállomány nagyon magas $(50 \%<)$ aránya. A folyamatot leíró matematikai modell figyelembe vette és változóként használta a bevándorlók számarányát (5 és 20\% között változtatva azt), a helyiek és bevándorlók között előforduló keresztházasságok arányát, s számszerüsítette azt a gazdasági és szociális előnyt, amelyet a bevándorlók élvezhettek. Mindezt tizenöt generációnyi időszakra vetítették ki, mely lefedi az angolszász vándorlás feltételezett kezdetétől egészen az Alfréd törvényeinek kihirdetéséig (890) ${ }^{3}$ tartó időszakot. A modell alapján egyértelmü, hogy még a bevándorló férfiak meglehetősen kis száma esetén is (5\%) - amennyiben azok nagy elönyöket élveztek, s a társadalom kellöképpen szegregált volt - akár öt generáció alatt is kialakulhatott a genetikai állományuk 50\% feletti aránya.

A Mark G. Thomas és kutatócsoportja által használt matematikai modell figyelmen kívül hagyott egy nagyon fontos aspektust. Kiindulási alapját egy nagy tömegü bevándorlás feltételezése jelentette, $\mathrm{s}$ nem számolt egyfajta folyamatos, lassú keveredéssel. Magas migrációs ráta, $0,3 \%$ vagy afeletti esetén (ez az Amerikai Egyesült Államok esetében napjainkban 0,3-0,4\% közé tehető) az 50\% feletti érték egyszeri nagy migrációs hullám nélkül, csupán a folyamatos kapcsolat és keveredés által is kialakulhatott. A másik ehhez, illetve a már említett regionális különbségekhez szorosan kapcsolódó probléma, hogy a genetikai vizsgálatok jellegéből adódóan a módszer az időbeli távlatok pontos meghatározására nem alkalmas. Így nem bizonyítható, hogy a keveredés mögött ténylegesen egy - jelen esetben az 5-7. századi angolszász - vándorlás áll, sőt, a regionális eltérések legyen szó akár a betelepülők arányáról, akár a genetikai távolságok viszonyáról - arra utalnak, hogy az egyes területeken más-más okok bújhatnak meg a keveredés mögött. Így például York és Norfolk esetében a magas kontinentális arány, illetve az, hogy az angliai klaszter északnémet/dán mintasorokhoz legközelebb eső elemeiről van szó, éppen arra mutat, hogy a keveredés mögött nem az angolszász bevándorlás, hanem inkább a viking kori migráció és a dán politikai fennhatóság (Danelaw) hatása feltételezhető (Weale et al., 2002). Teljes biztonsággal nem szürhető ki az újkori és legújabb kori migrációk hatása sem (Pattison,

\footnotetext{
${ }^{3}$ Alfréd törvénykönyve már jogilag nem különböztet meg különböző etnikai hátterű személyeket, így egy apartheidszerü berendezkedés feltételezése történelmileg nem megalapozott.
} 
2008), s mivel mind a helyi, mind a bevándorló lakosság genetikai összetételére modern adatokból következtetünk, a hiba esélye is nő, az egymással korábban is kapcsolatba lépő csoportok - melyek önmagukban sem biológiailag homogén egységek! - közti kis genetikai különbségek nehezen megfoghatóak.

Pontosabb képet kaphatunk a történeti DNS-en alapuló vizsgálatokból, melyek - amennyiben elfogadjuk a mintákat szolgáltató kontextus keltezését - egyértelmủen a vizsgálni kívánt populációról szolgáltatnak adatokat. Összesen tíz egyént vizsgáltak meg három Cambridge környéki, kelet-angliai lelőhelyröl (Schiffels et al., 2016). Ezek közül három a Kr. e. 1. és a Kr. u. 1. század közé keltezhető, míg hét a Kr. u. 5-8. század közé, azaz az angolszász vándorlás idejére. Lehetőség volt tehát az angolszász vándorlás által biztosan nem befolyásolt és az angolszász vándorlás idejére keltezett, ahhoz köthető minták egymással és modern mintasorokkal (walesi, skót és kelet-angliai, holland) való összehasonlítására. A modern walesi, skóciai és kelet-angliai népesség a jól elkülönülő vaskori és angolszász minták között helyezkedik el. Régészetileg sokkal érdekesebb viszont az 5-8. század közé keltezett minták szóródása. Döntő többségük, a hétből öt, a vaskori mintáktól távol helyezkedik el, s mintegy kialakítja az angolszász klasztert, míg egy az átmeneti, egy másik pedig egyértelmúen a vaskori tartományba esik. Az eredmények modern kelet-angliai mintasorokkal való összevetése alapján a terület mai népességének 38\%-a származik angolszász bevándorlóktól, ám ez továbbra sem adja meg az egykori bevándorlók számát vagy arányát.

Fontos régészeti tanulsággal jár viszont az egyes lelőhelyek egyéni vizsgálata. Az Oakingtonból származó négy minta azonos korú, az 5-6. század közé keltezhetőek, s leletanyaguk alapján a régészet bevándorlóként határozza meg őket. Genetikailag viszont a kép ennél jóval összetettebb: míg az 1. és 2. minta az angolszász tartományba esik, addig a 3. a már említett átmeneti, míg a 4. egyértelmúen a vaskori mintákhoz áll közel. Egyazon lelőhelyen, régészetileg hasonlóként meghatározott egyének genetikai háttere tehát alapvetően különbözik, s a csoportok keveredésére utal. Hixington-lelöhelyen viszont a három korabeli minta mindegyike keveredés nélküli bevándorlóra utal. A régészeti szempontból hasonló, egy kulturális egységbe - jelen esetben angolszászként meghatározott tartozó(nak vélt) személyek biológiai háttere nagyon eltérő lehet! Ez egyértelmüen bizonyítja, hogy az etnikumtól - melyet szerencsésebb egyfajta szituatív politikai identitásként, mintsem vérségi kötelék által összetartott csoportként felfogni (Geary, 1983) - nem várható el, hogy jól körülhatárolható, biológiai egységként jelentkezzen. A lelőhelyek közti különbség mutatja, hogy helyi szintủ narratívákra van szükség, és hogy a migráció és annak hatása univerzális modellekkel nem magyarázható, ahogy arra már a modern DNS-en alapuló vizsgálatok alapján kapott nagy, regionális eltérések is rámutattak.

A genetikai vizsgálatok eredményei rámutattak, hogy a migrációval és együttéléssel kapcsolatos régészeti modellek sokkal kisebb léptékben is relevánsak, 
mint ahogy a régészet eddig felhasználta azokat. Közösségi szinten elképzelhető a bevándorlók és a helyiek szegregációja, de keveredése is, ahogy előfordulhat helyi többségü, de adott esetben migráns többségú populáció is, de az arányok akár nemenként is változhatnak (harcos csoportok letelepedése stb.) (Härke, 2011). A vizsgálatok kiterjesztése a közeljövőben vizsgálhatóvá tehet olyan kérdéseket is, melyek a régészet kutatási lehetôségein kívül álltak, így például a vérségi kötelékek szerepét a kora középkori társadalmak szerveződésében.

Mit adhat tehát a genetika a régészet számára? A cikk terjedelmi korlátai miatt az említett vizsgálatok teljes bemutatására nem volt lehetőségem, bizonyos aspektusaikról nem ejtettem szót. A genetika önállóan nem képes megoldani ilyen összetett régészeti problémákat, viszont új, eddig hozzáférhetetlen információforrást jelent, s így más nézőpontból is vizsgálhatóvá tehet régi kérdéseket. Az angolszász migráció esetében talán nem képes pontosan meghatározni annak mikéntjét (egy nagy hullám, több hullám, folyamatos keveredés stb.) vagy pontos időpontját, viszont újra behozta a párbeszédbe, és árnyalta az elmúlt évtizedekben háttérbe szorult tömeges vándorlás teóriáját. Egyúttal azonban arra is rámutatott, hogy az angolszász migráció mindent elfedő és egységesítő nagy nyila alatt különbözőképpen lezajló, egyéni történetek húzódnak meg, rákényszerítve így a kutatást a nagy összefoglaló modellek újragondolására. Ez a kisléptékủ, közösségeket, sőt néha egyéneket középpontjába állító történeti genetikai megközelítés pedig megfelelő partnerre lelhet a régészet új, szintén a lehető legkisebb vizsgálható egységeket kereső, s azokból építkező kutatási irányaiban, mint az identitásrégészet vagy a háztartáskutatás.

\section{IRODALOM}

Capelli, C. et al. (2003): A Y Chromosome Census of the British isles. Current Biology, 13, 979984. DOI: 10.1016/S0960-9822(03)00373-7, https://goo.gl/XJrL9B

Geary, P. J. (1983): Ethnicity as a Situational Construct. (Mitteilungen der Anthropologischen Gesellschaft in Wien 113) Wien: Carl Gerold's Sohn, 15-26.

Hakenbeck, S. (2008): Migration in Archaeology: Are We Nearly There Yet? Archaeological Review from Cambridge, 23, 9-26. https://www.academia.edu/293108/Migration_In_Archaeology_Are_We_Nearly_There_Yet

Halsall, G. (2012): Archaeology and Migration: Rethinking the Debate. In: Annaert, R. et al.: The Very Beginning of Europe? Early-Medieval Migration and Colonisation $\left(5^{\text {th }}-8^{\text {th }}\right.$ Century). Archaeology in Contemporary Europe: Conference Brussels - May 17-19 2011. (Relicta Monografieën 7) Brussels: Flanders Heritage Agency, 29-40. https:/oar.onroerenderfgoed.be/ publicaties/RELM/7/RELM007-001.pdf

Härke, H. (2007): Invisible Britons: Gallo-Romans and Russians: Perspectives on Culture Change. In: Higham, N. J. (ed.): Britons in Anglo-Saxon England. Woodbridge: Boydell, 57-67.

Härke, H. (2011): Anglo-Saxon Immigration and Ethnogenesis. Medieval Archaeology, 55, 1-28. DOI: 10.1179/174581711X13103897378311, http://www.tandfonline.com/doi/abs/10.1179/174581 $711 X 13103897378311$ 
Millett, M. (1990): The Romanization of Britain: An Essay in Archaeological Interpretation. New York, NY: Cambridge University Press

Pattison, J. E. (2008): Is It Necessary to Assume an Apartheid-like Social Structure in Early Anglo-Saxon England? Proceedings of the Royal Society B. 275, 2423-2429. DOI: 10.1098/ rspb.2008.0352, https://www.ncbi.nlm.nih.gov/pmc/articles/PMC2603190/

Schiffels, S. et al. (2016): Iron Age and Anglo-Saxon Genomes from East England Reveal British Migration History. Nature Communications, 7. Article number: 10408, DOI:10.1038/ncomms10408, https://www.nature.com/articles/ncomms10408

Thomas, M. G. - Stumpf, M. P. H. - Härke, H. (2006): Evidence for an Apartheid Like Social Structure in early Anglo-Saxon England. Proceedings of the Royal Society B. 273, 2651-2657. DOI: $10.1098 / \mathrm{rspb} .2006 .3627$, https://www.academia.edu/468159/Evidence_for_an_apartheid-like_social_structure_in_early_Anglo-Saxon_England._Proceedings_of_the_Royal_Society_B_273_July_2006_2651-2657

Vai, S. et al. (2015): Genealogical Relationships between Early Medieval and Modern Inhabitants of Piedmont. PLoS ONE, 10, e0116801. DOI: 10.1371/journal.pone.0116801, http://journals.plos. org/plosone/article?id=10.1371/journal.pone. 0116801

Weale, M. E. et al. (2002): Y Chromosome Evidence for Anglo-Saxon Mass Migration. Molecular Biology and Evolution, 19, 1008-1021. DOI: 10.1093/oxfordjournals.molbev.a004160, https:// goo.gl/egFHYV 